\title{
PRODUK OLAHAN PEPAYA PADA KWT AL-MUHAJIRIN \\ DI KELURAHAN TAMALAREA JAYA \\ KECAMATAN TAMALANREA
}

\author{
Sitti Arwati dan Asriyanti Syarif \\ Prodi Agribisnis, Fakultas Pertanian Universitas Muhammadiyah \\ Email : sittiarwati@unismuh.ac.id
}

\begin{abstract}
Community service is to provide an overview of the benefits of papaya fruit and the composition of papaya as a fruit that can also be processed into jam and cake products through counseling. Provide training to housewives regarding the procedure for making jams and cakes from processed papaya. This community service was carried out in Tamalanrea Jaya Village, Tamalanrea District. This community service involves KWT Al Muhajirin in Tamalanrea Jaya Village as partners. The type of mature papaya that is chosen to be managed because this papaya is easily damaged and decomposes. This community service shows that the counseling and training process provided to partners regarding the importance of consuming papaya, papaya's nutritional content, degenerative diseases caused by lack of fruit consumption and training of cooked papaya products into jams and cakes goes well as seen from the positive response. given by partners and the high participation of partners in counseling and training activities carried out, activeness asks partners because of the desire to obtain information and multiply knowledge, the desire of partners to make processed papaya as a product that can increase family income.
\end{abstract}

Keywords: Diversification, papaya, KWT

\section{PENDAHULUAN}

Sektor pertanian menghasilkan produk-produk yang diperlukan sebagai input sektor lain terutama tekstil, industri makanan dan minuman. Pengembangan produk pertanian menjadi industri makanan dan minuman tidak terlepas dari pembangunan pertanian di pedesaan. Hal ini disebabkan karena sebagian tenaga kerja sektor pertanian berada di wilayah pedesaan.

Kelompok wanita adalah
merupakan kelompok yang besar

jumlahnya, menjalankan peran sebagai istri dan ibu rumah tangga (aspek domestic) dan juga berperan di aspek produktif (mencari nafkah) membantu suami dan keluarga untuk meningkatkan pendapatan.

Pepaya merupakan tanaman pekarangan yang dibudidayakan oleh manusia. Pepaya merupakan tauntunaman daerah tropis, walaupun bukan merupakan tanaman asli Indonesia, namun sudah tersebar dan berkembang di seluruh pelosok tanah 
air. Pepaya berasal dari Negara Florida, Hawai, India, Afrika Selaan dan Australia, dapat hidup di negara subtropis (Suprapti, 2005). Mengenai kandungan gizi dan unsur penting dalam papaya dapat dilihat pada Tabel 1.

Tabel 1.Kandungan Gizi dan unsur penting dalam buah papaya

\begin{tabular}{cccc}
\hline No. & Unsur Gizi & Pepaya mentah & Pepaya Matang \\
\hline 1. & Energy (kal) & 2.6 & 4.6 \\
2. & Protein (gr) & 2.1 & 0.5 \\
3. & Lemak (gr) & 0.1 & - \\
4. & Karbohidrat (gr) & 4.9 & 12.2 \\
5. & Kalsium (mg) & 50 & 23 \\
6. & Fosfor (mg) & 16 & 12 \\
7. & Besi (mg) & 0.4 & 1.7 \\
8. & Vit. A (SI) & 50 & 365 \\
9. & Vit. B (mg) & 0.02 & 0.04 \\
10. & Vit. C (mg) & 19 & 78 \\
11. & Air (gr) & 92.3 & 86.1 \\
\hline
\end{tabular}

Sumber : Direktorat Gizi Departemen Kesehatan RI, 2005.

Produksi pepaya di Sulawesi Selatan ditunjang dengan upaya budidaya tanaman ini pada lahan pekarangan, dan tiap daerah di Sulawesi Selatan memberikan kontribusi bagi peningkatan produksi pepaya terutama di daerah Enrekang dan Tanah Toraja.

Kelompok wanita merupakan mitra PKM, membudidayakan tanaman pepaya dalam lahan pekarangan yang dikonsumsi oleh mereka dalam bentuk buah dan dijual ke pasaran dalam bentuk utuh sebagai buah-buahan tanpa memproses menjadi sebuah produk yang dapat memberikan nilai jual yang tinggi dan juga nilai tambah. Pepaya kemudian dipanen dalam bentuk matang ditandai dengan kulit buah yang berwarna kuning.Kelebihan buah pepaya pada musim panen menyebabkan terjadi over supply sementara permintaan konsumen terhadap buah pepaya kecil kecuali pada momen ramadhan buah pepaya menjadi primadona. Buah pepaya pada akhirnya hanya dikonsumsi oleh rumah tangga mitra sebagai buah, dan bahkan ada yang membusuk karena tidak ada olahan produk. 
Aspek budidaya, pengolahan, dan pemasaran merupakan satu rantai yang menunjang dari usahatani pepaya yang dilakukan oleh mitra. Pada kenyataannya ketiga aspek tersebut belum sepenuhnya dikuasai oleh mitra, maka diperlukan upaya penyuluhan dan pelatihan yang dapat memberdayakan perempuan dalam Kelompok wanita Tani (KWT) dan memberikan informasi mengenai pemasaran pepaya dalam bentuk produk olahan pepaya.

Mitra yang terbentuk melalui kelompok wanita melakukan budidaya tanaman pepaya melalui pemanfataan pekarangan yang merupakan kumpulan ibu rumah tangga, memiliki permasalahan sebagai berikut :

a. Tanaman pepaya dibudidayakan dalam skala kecil dalam pekarangan rumah sebagai upaya pemanfaatan pekarangan. Hal ini disebabkan karena kurangnya informasi upaya peningkatan produksi, sehingga tidak terjadi peningkatan pendapatan bagi keluarga.

b. Peran perempuan dalam budidaya pepaya ada namun hanya pada tahapan usahatani dan panen sehingga upaya pengolahan pepaya menjadi produk yang memberikan nilai tambah belum sepenuhnya di lakukan oleh mitra.

c. Pepaya yang tidak dijual di pasar di konsumsi sebagai buah oleh mitra, namun jika tidak habis dikonsumsi mengakibatkan buah jadi rusak dan mengalami pembusukan.

Pemasaran merupakan hal yang utama dalam proses mendistribusikan produk ke konsumen, menjadi kendala mitra menjual pepaya kepada pedagang pengumpul dan tidak ada informasi pasar pada akhirnya market share yang diterima mitra kecil.maka perlu diberikan konsep manajemen pemasaran utamanya bila pepaya telah diolah menjadi produk diversifikasi.

\section{SOLUSI DAN LUARAN YANG DICAPAI}

Solusi merupakan sesuatu atau beberapa hal yang ditawarkan untuk mengatasi permasalahan yang dihadapi oleh mitra. Solusi yang dapat ditawarkan berupa penyuluhan dan pelatihan pembuatan diversifikasi produk olahan pepaya kepada ibu-ibu rumah tangg yang tergabung dalam kelompok wanita di Kelurahan Tamalanrea Jaya Kecamatan Biringkanaya Kotamadya Makassar. Kegiatan ini bertujuan memberikan pengetahuan dan informasi kepada ibu- 
ibu rumah tangga yang tergabung dalam kelompok wanita tentang bagaimana pentingnya meningkatkan produksi pepaya dari segi usahatatani, nilai manfaat dan gizi dari pepaya serta bagaimana mengolah aneka produk makanan dari pepaya dan memasarkan produk diversifikasi olahan pepaya.

Kegiatan ini diharapkan memberikan manfaat bagi beberapa pihak, diantaranya :

a. Bagi Ibu-ibu rumah tangga, diharapkan kegiatan ini memberikan minat dan motivasi bagi ibu-ibu rumah tangga petani meningkatkan produksi pepaya dengan lebih menggalakan usaha penanaman dan pemanfaatan lahan pekarangan, memberikan nilai tambah dari pengolahan pepaya.

b. Bagi pelaku bisnis, kegiatan ini diharapkan dapat berguna untuk menjadi pertimbangan salah satu alternatif usaha rumahan yang bisa dikembangkan dan memiliki prospek yang cerah.

c. Bagi masyarakat umum, ibu-ibu rumah tangga sebagai unit terkecil diharapkan dapat menyebarluaskan informasi yang diperoleh pada lingkungan tempat tinggal agar kegiatan ini menjadi bahan pertimbangan bagi masyarakat untuk membuat olahan pepaya yang dapat memberikan kontribusi bagi pendapatan keluarga.

luaran adalah produk berupa selai kaya pepaya dan kue pepaya (kue lumpur) yang dapat dikonsumsi oleh semua kalangan. Mengenai capaian luaran berupa : Jurnal Pengabdian Al-Ikhlas Universitas Islam Kalimantan, adanya peningkatan daya saing (peningakatan kualitas, kuantitas, dan nilai tambah) dari olahan pepaya, adanya penerapan iptek dalam teknologi dan manajemen, adanya produk olahan yang dihasilkan.

\section{METODE PELAKSANAAN}

Metode pelaksanaan kegiatan ini dilakukan dengan penyuluhan dan pelatihan pembuatan olahan pepaya pada KWT Al Muhajirin di Kelurahan Tamalanrea Jaya Kecamatan Tamalanrea dilakukan dengan beberapa tahapan sebagai berikut :

1. Penyuluhan

Ibu-ibu dikumpulkan dalam ruang pertemuan, setelah mereka berkumpul lalu diberikan metode ceramah mengenai pentingnya meningkatkan produksi pepaya dengan melakukan usahatani pepaya pada lahan pekarangan, manfaat 
mengkonsumsi pepaya, manfaat dan kandungan gizi pepaya, manfaat pepaya bagi kesehatan serta pemberian informasi bahwa pepaya dapat didiversifikasi menjadi produk selai kaya pepaya dan kue lumpur pepaya. Setelah diadakan metode ceramah, dilakukan kegiatan tanya jawab dengan ibu-ibu rumah tangga. Pada tahapan ini akan ada proses komunikasi antara pemateri dan anggota KWT Al Muhajirin dan proses transfer pengetahuan.

2. Pelatihan pembuatan olahan pepaya Ibu-ibu yang terjalin dalam mitra berkumpul pada kegiatan demonstrasi pembuatan olahan pepaya. Pada kegiatan ini akan terjadi pengenalan inovasi teknologi pengolahan pepaya dan proses adopsi teknologi pengolahan pepaya menjadi selai kaya pepaya dan kue oleh ibu-ibu rumah tangga yang tergabung dalam KWT Al Muhajirin. Ini terdiri dari beberapa langkah-langkah sebagai berikut :

1) Anggota KWT yang merupakan mitra, terdiri dari 10 orang perempuan.

2) Pada pemberian pelatihan ini diajarkan proses pembuatan selai kaya pepaya dan saos pepaya. Masing-masing kelompok terdiri dari 5 orang dan didampingi asisten yang sudah terampil. Kelompok pertama selai kaya, kelompok kedua membuat kue lumpur pepaya. Sebelum melakukan demonstrasi pembuatan produk olahan pepaya di perkenalkan bahan-bahan yang digunakan terutama pepaya dan alat-alat yang digunakan, biaya yang dikeluarkan untuk pembelian bahan-bahan serta manfaat dari pembuatan olahan dari pepaya.

Adapun bahan baku yang digunakan :

a. Selai kaya pepaya

1. 1 buah pepaya matang

2. santan dari 2 butir kelapa (jangan dicampur air)

3. gula pasir, sebanding atau kurang dari volume santan (misal: santan 2 gelas, gula pasir juga 2 gelas; kurangi jumlah gula pasir jika tidak ingin terlalu manis)

4. 10 butir kuning telur ayam (boleh saja tambahkan 2 atau 3 buah putih telur).

5. 2 3 lembar daun pandan (disimpul) 
6. 1 sdm mentega cair (untuk memperindah warna)

7. 1/4 sdt bubuk vanili (optional)

8. air untuk men-tim secukupnya

9. gula merah 300 gram

b. KUE LUMPUR PEPAYA

BAHAN :

$\checkmark 200$ GRAM PEPAYA YANG TELAH DIHALUSKAN

$\checkmark \quad 150$ GR GULA PASIR

$\checkmark$ 200-250 GR TERIGU

$\checkmark 50$ GR MARGARIN

DICAIRKAN

$\checkmark$ SANTAN $200 \mathrm{ML}$

$\checkmark$ VANILI

$\checkmark$ SUSU BUBUK $1 \frac{1}{2}$ SACHET

$\checkmark$ TELUR 1 BUTIR

Cara membuat :

1. Kocok telur dengan gula

2. Masukkan pepaya yang telah dihaluskan

3. Masukkan santan

4. Masukan mentega yang telah dicairkan

5. Masukkan terigu dan susu bubuk

6. Aduk dan tambahkan vanili

7. Kemudian olesi Loyang/cetakan kue lumpur dengan mentega

8. panaskan Loyang/cetakan kue lumpur
9. masukkan adonan ke dalam Loyang dan tutup

10. stelah setengah matang taburi kismis dan chery sebagai hiasan

11. angkat dan sajikan

Setelah demonstrasi produk olahan dari pepaya (selai kaya dan kue), maka kelompok ibu-ibu rumah tangga yang tergabung dalam kelompok wanita dapat mencicipi produk yang diformulasi dengan menggunakan pepaya, serta dijelaskan manfaat dari pembuatan produk ini berupa : konsumsi buah dapat ditingkatkan dengan diversifikasi produk dari buah pepaya, memenuhi kebutuhan semua kalangan serta peluang usaha bagi ibu RT untuk skala industri rumah tangga.

Setelah pembuatan produk olahan dilakukan maka dilakukan penyuluhan untuk memberikan strategi pemasaran bagi mitra, memberikan trik dan tips dalam melakukan penjualan dan menjalin kerjasama dengan lembaga pemasaran, koperasi sebagai unit usaha.

\section{HASIL DAN PEMBAHASAN}

Pelaksanaan

kegiatan pengabdian masyarakat berupa kegiatan penyuluhan dan pelatihan pembuatan produk olahan pepaya dengan mitra KWT Al Muhajirin Kelurahan 
Tamalanrea Jaya Kecamatan Tamanrea.

Peserta kegiatan penyuluhan dan pelatihaan produk oalahan pepaya $\mathrm{s}$ berjumlah 10 orang.

Kegiatan Penyuluhan dilakukan dengan materi yang disampaikan ke mitra berupa, fakta pentingnya makan buah pepaya, kandungan gizi pepaya, penyakit degenaratif yang ditimbulkan karena kurang mengkonsumsi pepaya dan diversifikasi produk olahan pepaya menjadi selai kaya pepaya dan kue lumpur pepaya. Pada kegiatan penyuluhan masing-masing peserta diberikan hand out mengenai materi yang dipaparkan, setelah pemateri memaparkan materi maka dibuka sesi tanyajawab yang dibagi kedalam 3 sesi, dimana pada sesi tanyajawab peserta antusias bertanya kepada pemateri, sebagian berkeluh kesah mengenai susahnya membiasakan mengkonsumsi buah-buahan bagi anak-anak dan bagi mereka sendiri selain hanya membuat es buah.

Hasil akhir dari kegiatan penyuluhan yang diberikan yakni mitra menjadi paham akan pentingny mengkonsumsi pepaya sesuai angka kecukupan gizi setiapharinya, mitra juga mengetahui berbagai penyakit degeneratif yang sudah umum di masyarakat, yang diakibatkan karena kurangnya mengkonsumsi pepaya, mitra jugamemiliki alternative lain untuk menyajikan buah pepaya dalam bentuk yang lebih variatif dan disukai anak-anak dan juga dewasa.

Kegiatan pelatihan pembuatan produk olahan pepaya, dimana pelatihan di lakukan di Salah satu rumah anggota KWT Al muhajirin di Kelurahan Tamalanrea Jaya Kecamatan Tamalanrea, dengan jumlah peserta sebanyak 10 Orang. Sebelum pelatihan dimulai masing-masing peserta diberikan hand out agar lebih memudahkan jalannya pelatihan. Produk olahan pepaya yang di buat adalah selai kaya pepaya dan kue lumpur pepaya dengan bahan dasar pepaya atang. Pemilihan jenis sayuran dilandaskan atas permintaan mitra karena KWT Al Muhajirin sebagian besar anggota kelompok ini membudidayakan tanaman pepaya pada halaman rumah mereka.

Pada kegiatan pelatihan ini jenis pepaya yang digunakan adalah pepaya matang yang di buat dengan metode yang semudah mungkin, dan dengan menggunakan jenis bahan yang tidak terlalu banyak dan mudah didapatkan. Pembuatan selai kaya pepaya dan kue 
lumpur mudah juga mereka praktekkan dan menggunakan peralatan yang sederhana.

Pada kegiatan pelatihan pembuatan selai kaya pepaya bahanbahan yang digunakan adalah pepaya matang, gula merah, dan santan sebagai bahan utama. Adapun langkah pertama yang dilakukan yaitu menghancurkan pepaya dan menghaluskannya dengan menggunakan blender, seltelah itu dicampurkan dengan gula merah dan santan dimasak sampai mengental. Dan gula pasir juga digunakan agar selai terjadi proses pemanisan dan mencegah terjadinya proses penjamuran dan selai dibisa disimpan dalam jangka waktu yang lama.

Proses pembuatan kue lumpur, bahan baku utamanya pepaya yang dicampurkan dengan terigu, telur, gula, vanili, garam. Sedangkan kismis dan chery digunakan sebagai penghias kue agar tampak menarik. Kue ini menggunakan cetakan kue lumpur yang terbuat dari besi atau aluminium.Sekilas jika diliat menurut anggota KWT kue lumpur pepaya menyerupai kue lumpur kentang, namun setelah dicoba maka akan dirasakan buah pepaya.

Pada kegiatan pelaksanaan penyuluhan dan pengabdian anggota
KWT Al Muhajirin di suguhkan selai dalam botol/toples, kemudian kami memberikan roti tawar untuk mereka mencicipi selai ini dengan olesan selai ke atas roti, dan menurut pendangan mereka rasanya mirip dengan selai kaya biasa yang hanya menggunakan gula merah dan santan saja sebagai bahan baku.

Pada kegiatan pembuatan kue lumpur kami memberikan kue lumpur sebanyak 20 buah untuk mereka cicipi sambil kami mempraktekkan proses pembuatan kue lumpur pepaya. Menurut pandangan mereka enak dan merupakan terobosan pengolahan pepaya. Menurut anggota KWT, mereka hanya mengenal olahan pepaya dalam bentuk buah yang dikonsumsi langsung dan sebagai campuran es buah. Mereka baru memahami bahwa pepaya dapat di buat aneka produk dan dapat dimanfaatkan untuk meningkatkan pendapatan dan memberikan nilai tambah pada produk buah pepaya.

\section{FOTO KEGIATAN}

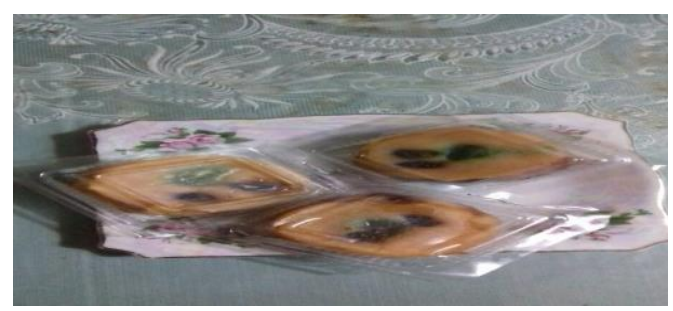

Gambar 1. Kue Lumpur Pepaya 


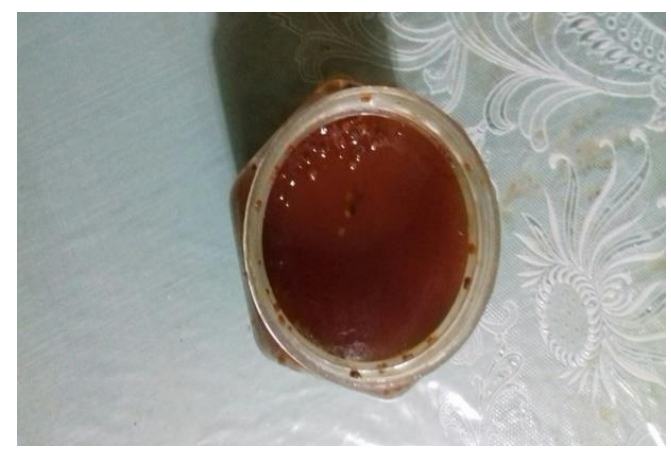

Gambar 2. Selai Kaya Pepaya

\section{KESIMPULAN DAN SARAN}

\section{Kesimpulan}

Hasil kegiatan PKM produk olahan pepaya pada KWT Al Muhajirin di Kecamatan Tamalanrea Jaya Kecamatan Tamalanrea dapat disimpulkan bahwa proses penyuluhan dan pelatihan yang diberikan kepada mitra binaan yaitu KWT Al Muhajirin dalam hal ini penyampaian pentingnya mengkonsumsi pepaya, kandungan gizi pepaya, penyakit degenaratif yang ditimbulkan karena kurang mengkonsumsi pepaya dan pelatihan diversifikasi produk olahan pepaya menjadi selai kaya dan keu lumpur berjalan dengan baik terlihat dari respon positif yang diberikan mitra dan tingginya partisipasi mitra dalam kegiatan penyuluhan dan pelatihan yang dilaksanakan.

\section{Saran}

Pepaya memberikan nilai ekonomis jika diolah dengan baik dan memberikan nilai tambah serta memberikan beberapa produk olahan. Namun pengetahuan dan keterampilan ibu-ibu ruah tangga yang tergabung dalam anggota KWT masih terbatas, maka perlu upaya pendampingan dalam pengolahan produk dan pemasaran bila anggota KWT memiliki keinginan membaut industri rumah tangga.

\section{DAFTAR PUSTAKA}

Dinas Pertanian Tanaman Pangan dan Hortikultura, 2017. Data Produksi Pepaya Di Sulawesi Selatan. Provinsi Sulawesi Selatan.

Dinas Pertanian Tanaman Pangan dan Hortikultura, 2017. Data Produksi Pepaya di Kabupaten Bantaeng. Provinsi Sulawesi Selatan.

Direktorat Gizi, 2005. Kandungan Gizi buah Pepaya. Departemen Kesehatan Republik Indonesia, Jakarta.

Suprapti, 2005. Budidaya Tanaman Pepaya. Penebar Swadaya, Jakarta. 